Krzysztofa Jakubiaka, prof. dra hab. Jana Krukowskiego, prof. dr hab. Dorotę Żołądź-Strzelczyk, prof. dr hab. Agnieszkę Stopińską-Pająk, prof. dr hab. Eleonorę Sapię-Drewniak.

IV Walne Zebranie Członków Towarzystwa Historii Edukacji przyjęło cztery główne uchwały:

- uchwałę w sprawie przywrócenia nazwy przedmiotu „historia wychowania” w standardach kształcenia na studiach pedagogicznych;

- trzy uchwały o nadaniu członkostwa honorowego w THE (przyjęte jednogłośnie i przy gromkich brawach) prof. dr hab. Karolowi Poznańskiemu, prof. dr hab. Józefowi Miąso, prof. dr hab. Lechowi Mokrzeckiemu.

(red.)

\title{
Otwarte spotkanie wladz statutowych Towarzystwa Historii Edukacji Kielce, 17 listopada 2008 r.
}

W dniu 17 listopada, we Wszechnicy Świętokrzyskiej w Kielcach, miało miejsce uroczyste, otwarte posiedzenie władz statutowych Towarzystwa Historii Edukacji. Spotkanie, ściśle związane z jubileuszem 90-lecia niepodległości Polski, przebiegało pod hasłem „Niepodległość i wychowanie. Z doświadczeń II Rzeczypospolitej”. W obradach uczestniczyło wielu czołowych przedstawicieli historii wychowania pod przewodnictwem prezesa Wiesława Jamrożka. Celem spotkania było zainicjowanie, planowanej na rok 2009, ogólnokrajowej dyskusji naukowej nad spuścizną teorii wychowania obywatelskiego okresu międzywojennego.

Spotkanie zarządu rozpoczęto od złożenia kwiatów pod pomnikiem Czwórki Legionowej w Kielcach.

Obrady zainaugurował prof. dr hab. Karol Poznański, przypominając zebranym odrodzenie i przebudowę systemu kształcenia i wychowania po odzyskaniu niepodległości. Zarówno manifest powstałego w Lublinie 6/7 listopada 1918 r. Tymczasowego Rządu Ludowej Republiki Polskiej, jak i późniejszy manifest rządu z 21 listopada tego roku zapowiadał utworzenie powszechnej, świeckiej i dostępnej dla wszystkich dzieci bezpłatnej szkoły. W latach 1919-1921 wprowadzono do szkół powszechnych nowe programy nauczania. Powoli realizowano zasadę jednolitości szkolnictwa. Postęp w rozwoju oświaty był możliwy dzięki wzrostowi w budżecie państwa wydatków na oświatę. Było to o tyle istotne, że Polska pod względem oświatowym należała w Europie do państw o największym zacofaniu.

Powyższy wątek kontynuowała w swoim wystąpieniu (zatytułowanym „Nadzieje i rzeczywistość”) prof. dr hab. Kalina Bartnicka. Referentka podkreśliła m.in., że po odzyskaniu niepodległości, w okresie ustalania granic i formowania się państwa, w oświacie najważniejszym problemem było ujednolicenie odziedziczonego po zaborach szkolnictwa, polonizacja programów kształcenia oraz wprowadzenie obowiązku szkolnego na 
całym terytorium odrodzonego państwa polskiego. Najżywsze spory toczyły się wokół poziomu szkoły elementarnej, którą przekształcono w powszechną oraz likwidacji dualizmu szkolnego, drożności systemu szkolnego. Towarzystwo Nauczycieli Szkół Wyższych, i znany pedagog Tadeusz Lopuszański, kładli nacisk na wysoki poziom i pewien elitaryzm szkoły średniej, gimnazjum. Demokratyczne społecznie i bardzo postępowe pedagogicznie były postulaty Zrzeszenia Nauczycielstwa Polskich Szkół Początkowych oraz publikacje Stefanii Sempołowskiej żądającej wysoko zorganizowanej szkoły powszechnej i rozbudowanej opieki nad dzieckiem. W tym kierunku przygotowany został w Ministerstwie Oświaty i Wyznań Religijnych tzw. Program K. Praussa, poparty przez uchwały I Wielkiego Zjazdu Nauczycielstwa Polskiego w kwietniu 1919 r. w Warszawie (tzw. Sejmu Nauczycielskiego). Prof. K. Bartnicka stwierdziła, że zradykalizowane przez wojnę nastroje opinii publicznej i demokratyzm rzesz nauczycielskich miały wpływ na decyzje rządowe w sprawach oświatowych. Pierwsze dekrety, ustawy, rozporządzenia, wreszcie zapisy Konstytucji 1921 r. dotyczące systemu oświaty i wychowania, były uderzająco postępowe społecznie i demokratyczne. Wbrew pesymistycznym nastrojom i trudnościom pierwszych lat niepodległości w zasadzie do $1922 \mathrm{r}$. zbudowane zostały podstawy polskiego szkolnictwa $i$ oświaty.

Prof. dr hab. Adam Massalski wygłosił, przygotowany wspólnie z dr Ewą Kulą artykuł na temat znaczenia krajoznawstwa w wychowaniu w ujęciu pedagoga i regionalisty Edmunda Massalskiego (1886-1975). E. Massalski należał do pokolenia Polaków, którzy budowali zręby niepodległego państwa Polskiego po przeszło 100 latach niewoli narodowej. Jego działalność na polu krajoznawstwa i regionalizmu oparta była na dążeniu do poznania własnej ojczyzny, którą to ideę propagował w pracach Polskiego Towarzystwa Krajoznawczego. Ruch krajoznawczy był dla E. Massalskiego podstawowym elementem wychowania patriotycznego. W referacie przedstawiono ponadto zainteresowania i osiągnięcia naukowe E. Massalskiego.

Następnie głos zabrał prof. dr hab. Adam Winiarz, który wygłosił referat pod tytułem „Aksjologiczne i teleologiczne aspekty wychowania obywatelskiego w II Rzeczypospolitej”. W referacie autor zadał pytania: 1) Jakie wartości próbowano zaszczepić u młodzieży w procesie wychowania obywatelskiego?, 2) Za pomocą jakich metod wychowawczych chciano tego dokonać?, 3) W jakich formach organizacyjnych realizowano zadania wychowania obywatelskiego?

W swoim wystąpieniu podkreślił, że począwszy od epoki Oświecenia relacje między państwem a szkołą kształtującą postawy obywatelskie młodego pokolenia, stały się przedmiotem rosnącego zainteresowania zarówno sfer rządowych, jak i publicystyki. W warunkach polskich zagadnienie właściwego z punktu widzenia interesu narodowego i państwowego wychowania obywatelskiego było sprawą szczególnej wagi.

Jako następna głos zabrała prof. dr hab. Hanna Wójcik-Łagan z Uniwersytetu Humanistyczno-Przyrodniczego im. Jana Kochanowskiego w Kielcach. Zaprezentowała referat pt. „Józef Piłsudski w szkolnej edukacji historycznej w latach trzydziestych XX wieku". Historia, jako przedmiot szkolny w tym okresie pełniła rolę służebną wobec oczekiwań politycznych obozu rządzącego. Autorka odpowiadała m.in. na pytanie, w jaki sposób odbywał się przekaz treści propagandowych, w których istotną rolę odgrywała osoba Józefa Piłsudskiego. 
Kolejny referent, prof. dr hab. Roman Tomaszewski, zaprezentował artykuł pod tytułem „Czynnik wojskowy w oddziaływaniu na społeczeństwo II Rzeczypospolitej”. Symbolem odzyskania niepodległości stał się 11 listopada 1918 r., data ściśle utożsamiana $\mathrm{z}$ wysiłkiem militarnym społeczeństwa polskiego, będącym podstawą odtworzenia państwa.

Społeczne uznanie dla poświęcenia legionistów, a następnie zwycięstwa z $1920 \mathrm{r}$. umożliwiły przeniknięcie tej tradycji do systemu wychowania II Rzeczypospolitej. Wyprowadzany $\mathrm{z}$ lat 1908-1921 etos wychowania wojskowego wykroczył poza krąg środowisk wojskowych i stał się ważną składową powszechnego wychowania w Polsce do 1939 r.

W przeddzień uroczystego spotkania poświęconego 90 rocznicy odzyskania przez Polskę niepodległości odbyło się także wieczorne robocze posiedzenie Zarządu THE. Podjęto na nim bieżące sprawy organizacyjne Towarzystwa.

Ewa Kula, Marzena Pękowska 